\title{
GENETISCHE UNTERSCHIEDE ZWISCHEN VERGLEICHSTIEREN UND DEREN EINFLUSS AUF DIE ZUCHTWERTSCHÄTZUNG
}

\author{
J. Lederer, O. Vogt-Rohlf. - Rechenzentrum zur Förderung der Landwirtschaft in Nieder- \\ sachsen, 3090 Verden, Heideweg 1, BRD.
}

Für die Schwarzbuntpopulation Niedersachsens wurde untersucht, welche genetischen Unterschiede zwischen den einzelnen Gruppen von Vergleichstieren bestehen. Dazu wurden zwei LSQ-Analysen durchgeführt. Bei der ersten wurden die Region, das Erstkalbealter und die Kalbesaison als fixe Effekte sowie das Herden-niveau als lineare Regression berücksichtigt. Die zweite enthielt zusatzlich noch die Väter als zufällige Effekte. Aus der Differenz zwischen den LSQ-Konstanten aus den beiden Analysen wurde dann auf die genetischen Differenzen geschlossen.

Die Auswertungen, die auf 85473 Färsenleistungen des Prüfungsjahres 1973-74 basieren, brachten folgende Ergebnisse :

I. Zwischen den 5 Kalbesaisonklassen bestehen keine genetischen Unterschiede.

2. Zwischen den Regionen lassen sich solche von - 50, I $\mathrm{kg}$ bis $+84,4 \mathrm{~kg}$ bei der Milchmenge, von - I,77 kg bis $+3,2 \mathrm{I} \mathrm{kg}$ bei der Fettmenge und von - o,009 p. 10o bis + 0,029 p. Ioo beim Fettgenalt erkennen.

3. Die höchste EKA-Klasse ( $34-3^{8}$ Mon.) weist gegenüber der niedrigsten ( $22-25$ Mon.) eine deutliche genetische Differenz auf, und zwar von $-39,4 \mathrm{~kg}$ bis $+46,6 \mathrm{~kg}$, von $-\mathrm{I}, 79 \mathrm{~kg}$ bis $+2,00 \mathrm{~kg}$ und von $-0,004$ p. I00 bis $+0,003$ p. roo bei Milchmenge, Fettmenge bzw. Fettgehalt.

4. Das zunehmende genetische Niveau bei steigender Herdenleistung war aus der Abnahme der Regression nach Ausschaltung der Vatereffekte ersichtlich. Bei Berücksichtigung dieses Faktors als fixen Effekt ( 12 Klassen) konnten für die 3 untersuchten Merkmale genetische Unterschiede von $-53,2 \mathrm{~kg}$ bis $+34,5 \mathrm{~kg}$, von $-2,31 \mathrm{~kg}$ bis $+3,66 \mathrm{~kg}$ und von $-0,008 \mathrm{p}$. 100 bis 0,005 p. Ioo zwischen dem niedrigsten und hochsten Herdenniveau geschätzt werden.

Mit erwartungstreuen Schätzergebnissen für den Zuchtwert kann somit nur bei Berücksichtigung der Väter der Vergleichstiere gerechnet werden.

\section{SOME GENETIC FERTILITY PARAMETERS}

OF THE ROMNEY MARSH SHEEP IN POLAND

M. J. Radmomska, L. Ubysz, J. Klewiec. - Institute of Biological Basis of Animal Brecding, Warszawa, Poland.

The coefficients of repeatability $(t)$ and heritability $\left(h^{2}\right)$ of the fertility of the Romney Marsh ewes in Poland were estimated on the basis of data from three breed flocks. It has been proved that repeatability and heritability of the fertility in the first lambing is low, similarly as heritability of the lifelong fertility. On the other hand, the value of $h^{2}$ of the fertility proved to be relatively high in the first lambing $(0,403)$, what allows to presume that the results of the third lambing could constitute a criterion of selection for this feature.

\section{A SELECTION PROGRAMME FOR TROTTING HORSES}

H. KräUsslich, M. Th. Linner and K. Osterkorn. - Institut für Tierzucht und tierhygiene der Ludwerig-Maximilians-Universität München, 8 Veterinärstrasse 13, 8 München 22.

In 1973, the population of trotters in the F.R. Germany amounted to approximately 3 ooo mares and I80 stallions. The "Trotting Races Calendars" published in 1973 contain data on 3988 trotting horses with an average of $\mathrm{I}_{3}$ racing times per trotter. Racing times per $\mathrm{I}$ ooo $\mathrm{m}$ are adjusted to sex, age, and conditions of race course. The deviations of adjusted racing times from the mean value of the race course are used for the calculation of genetic parameters. Heritability 
estimates are $h^{2}=0.36\left(s_{\mathrm{h}}{ }^{2}=0.172\right)$ for three year old trotters and $h^{2}=0.25\left(s_{\mathrm{h}}^{2}=0.048\right)$ over all age groups. The expected selection response after selection on racing performance of three year old stallions and mares has been calculated. It amounts to 2.03 seconds per generation if selection is only applied on the male path, and 2.57 seconds per generation after selection on the male and the female path. Assuming a generation interval of five years on the male side and of ro years on the female side, the expected selection response per year amounts to 0.34 seconds or $0 .+\mathrm{p}$. Ioo. The record times of trotters have increased during a period of 120 years by I minute which makes an average increase of 0.50 seconds per year.

\section{GENETISCHE KOVARIANZ ZWISCHEN UMNITTELBAREM UND MÜTTERLICHEM EFFEKT JE NACH DER RICHTUNG DER INNERFAMILIENMÄSSIGEN SELEKTION FÜR DAS KÖRPERGEWICHT IM ALTER VON 2I TAGEN BEI MÄUSEN}

\section{T. Slawinski. - Agricultural Academy Institute of Biological Basis of Animal Breeding, Wars- zawa, Poland.}

Im Ergebnisse der während der Io Generationen geführten Zweirichtungsselektion für das Körpergewicht im Alter von 2 I Tagen wurden 3 Linien von Mäusen, und zwar : C - mit grossem Körpergewicht, L - mit kleinem Körpergewicht und $\mathrm{O}$ - nichtselektionierte Kontrollinie, erhalten. Nach 8 Generationen der Selektion wurde ein Versuch durchgeführt, in welchem die Jungmäuse aller 3 Linien den Weibchen zur Fütterung kreuzmässig untersetzt waren. Im Ergebnisse wurden 6-Stück-Mäusegruppen erhalten, die volle durch eigene Mütter (je 2 Stück) und durch die Weibchen zweier übrigen Linien (auch je 2 Stück) aufgezüchteten Geschwister umfassten. Auf Grund der Messungen von 1108 Mäusen der Ausgangspopulation wurden die Körpergewichtsparameter genetisch abgeschätzt. Auf Grund des Selektionseffektes wurden unmittelbare und korrelierte Reaktionen auf Selektion, berechnet als Regression von Differenzen zwischen den Mittleren der den Generationen entgegengestellten Linien, abgeschätzt. Auf Grund der Differenz zwischen der Kovarianz der vollen durch eigene Mütter und dieser durch die Ammen genetisch unterschiedlicher Linien aufgezüchteten Geschwister wurde die genetische Kovarianz zwischen unmittelbarem und postnatalem mütterlichem Effekt ermittelt.

Es wurde eine negative genetische Kovarianz zwischen obigen Effekten in selektionierten Linien und eine positive genetische Kovarianz in der Kontrollinie erhalten.

Im Zusammenhang mit den genetisch hohen Korrelationskoeffizienten zwischen dem Körpergewicht im Alter von 12,42 und 56 Tagen $\left(r_{\mathrm{G}}=0,8\right.$ bis $\left.\mathrm{I}, \mathrm{o}\right)$ und einem unterschiedlichen Zeichen der genetischen Kovarianz in den selektionierten Linien und in der Kontrollinie wurde die Hypothese gestellt, dass die Korrelation zwischen dem unmittelbaren genetischen Effekt des Körpergewichte und dem genetischen postnatalen Effekt vom nichtpleiotropischen Charakter sei.

\section{RECOMBINATION OF BLOOD GROUP FACTORS IN THE $B$ SYSTEM IN CATTLE}

\section{Z. Dorynek, A. Kaczmarek. - Agricultural Academy, Posnaì, Poland.}

Bei I 949 Kälbern wurden die Blutgruppen in Io Systemen unter Anwendung von 58 Sera bestimmt, wobei 20 Sera zur Identifizierung der zum $B$-System gehörenden Antigene dienten. In zwei Fällen wurde eine irregulare Blutgruppenvererbung im $B$-System festgestellt, was als Folge von Crossing-over betrachtet werden kann.

\section{EXTENDED PART-LACTATIONS ON THE BASIS OF IAST TESTDAY MILK YIELD}

\footnotetext{
T. Aurax. - Department of Animal Genetics and Breeding, Agricultural University of Norway, Ås-NLH, Norway.

A study concerning extention of part-lactation records is done on about 6200 first and 4 I 50 second - to fifth lactations records from the milk recording in Norway. The monthly and cumulative montly milk yield records were pre-adjusted for the effect of age, month of calving, herd, length of first period and calving interval.
} 